\title{
NITROGEN FERTILIZER USE EFFICIENCY, RECOVERY AND LEACHING OF AN ALEXANDERGRASS PASTURE(1)
}

\author{
Laércio Ricardo Sartor ${ }^{(2)}$, Tangriani Simioni Assmann ${ }^{(3)}$, \\ André Brugnara Soares ${ }^{(3)}$, Paulo Fernando Adami ${ }^{(2)}$, \\ Alceu Luiz Assmann ${ }^{(4)}$ \& Christiano Santos Rocha Pitta ${ }^{(2)}$
}

\begin{abstract}
SUMMARY
Nitrogen usually determines the productive potential of forage crops, although it is highly unstable in the environment. Studies on recovery rates and use efficiency are important for more reliable fertilizer recommendations to reduce costs and avoid environmental pollution. The purpose of this study was to evaluate $\mathrm{N}$ use efficiency and recovery rate of Alexandergrass pasture (Brachiaria - Syn. Urochloa plantaginea) as well as $\mathrm{N}-\mathrm{NO}_{3}{ }^{-}$and $\mathrm{N}-\mathrm{NH}_{4}{ }^{+}$soil concentrations using different levels of $\mathrm{N}$ fertilization under two grazing intensities. The experiment was arranged in a randomized block design in a factorial scheme with three replications. Treatments consisted of three $N$ rates $\left(0,200\right.$ and $\left.400 \mathrm{~kg} \mathrm{ha}^{-1} \mathrm{~N}\right)$ and two grazing intensities termed low mass (LM; forage mass of $2,000 \mathrm{~kg} \mathrm{ha}^{-1}$ of DM) and high mass (HM; forage mass of $3,600 \mathrm{~kg} \mathrm{ha}^{-1}$ of DM) under continuous stocking and variable stocking rates. Results of $\mathrm{N}$ fertilization with $200 \mathrm{~kg} \mathrm{ha}^{-1}$ were better than with $400 \mathrm{~kg} \mathrm{ha}^{-1} \mathrm{~N}$. There was a significant effect of $\mathrm{N}$ rates on soil $\mathrm{N}-\mathrm{NO}_{3}{ }^{-}$ concentration with higher levels in the first layer of the soil profile in the treatment with $400 \mathrm{~kg} \mathrm{ha}^{-1} \mathrm{~N}$. Grazing intensity also affected soil $\mathrm{N}-\mathrm{NO}_{3}{ }^{-}$concentration, by increasing the levels under the higher stocking rate (lower forage mass).
\end{abstract}

Index terms: Forage production, inorganic N, soil fertility, urea.

\footnotetext{
(1) Received for publication in April 2010 and approved in February 2011.

(2) Estudantes do Programa de Pós-Graduação em Agronomia, UTFPR. Via do Conhecimento, km 1, CEP 85501-290 Pato Branco (PR). E-mails: laerciosartor@hotmail.com; paulof_adami@hotmail.com; chrpitta@yahoo.com.br

(3) Professores do Programa de Pós-Graduação em Agronomia, UTFPR. E-mails: tangriani@utfpr.edu.br; soares@utfpr.edu.br

(4) Pesquisador da Unidade Regional de Pesquisa Pato Branco / Instituto Agronômico do Paraná - IAPAR. BR 158, km 497, Bairro Bom Retiro, Caixa Postal 510, CEP 85505970 Pato Branco (PR). E-mail: assmann@iapar.br
} 


\title{
RESUMO: EFICIÊNCIA DE USO DA ADUBAÇÃO NITROGENADA, RECUPERAÇÃO E LIXIVIAÇÃO DO NITROGÊNIO EM PASTAGEM DE CAPIM-PAPUÃ
}

\begin{abstract}
$O N$ possui elevada instabilidade no ambiente e determina o potencial produtivo de forrageiras. O estudo da eficiência de uso e dos teores do nutriente no solo possibilita a recomendação adequada de adubação nitrogenada, procurando a redução dos custos de produção e poluição ambiental. Objetivou-se neste trabalho avaliar a eficiência de uso, as taxas de recuperação do $N$ de uma pastagem de capim-papuã (Brachiaria plantaginea) e os teores de $\mathrm{N}-\mathrm{NO}_{3}{ }^{-}$e N-N $\mathrm{NH}_{4}{ }^{+}$no solo com uso de diferentes doses de adubação nitrogenada e duas massas de forragem, sob pastejo. O experimento foi conduzido no delineamento experimental de blocos a acaso, com os tratamentos em esquema fatorial. Os tratamentos consistiram da combinação de três doses de $N\left(0,200\right.$ e $400 \mathrm{~kg} \mathrm{ha}^{-1}$, utilizando ureia) e duas massas de forragem (massa baixa com $2.000 \mathrm{~kg} \mathrm{ha} \mathrm{h}^{-1}$ de MS e massa alta com $3.600 \mathrm{~kg} \mathrm{ha}^{-1}$ de MS) em

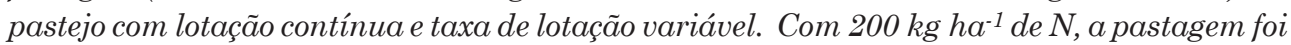
mais eficiente na utilização do nutriente, não sendo responsiva a dose de $400 \mathrm{~kg} \mathrm{ha}^{-1} \mathrm{de} \mathrm{N}$. Observou-se efeito das doses de $\mathrm{N}$ no teor de $\mathrm{N}-\mathrm{NO}_{3}{ }^{-}$no solo, indicando maiores concentrações nas camadas superficiais e acúmulo de $N$ mineral nos tratamentos com $400 \mathrm{~kg} \mathrm{ha}^{-1} \mathrm{de} N$ durante o período experimental. Diferenças entre as massas de forragem também foram encontradas para os teores de $\mathrm{N}_{-} \mathrm{NO}_{3}^{-}$; no solo com menor massa de forragem, caracterizada por maior taxa de lotação, os teores de $\mathrm{N}-\mathrm{NO}_{3}$ foram maiores.
\end{abstract}

Termos de indexação: fertilidade do solo, $N$ inorgânico, produção de forragem, ureia.

\section{INTRODUCTION}

Studies on $\mathrm{N}$ dynamics in the soil-plant system and in specific species characterize the efficiency of the recommended $\mathrm{N}$ fertilization in agriculture and animal husbandry, and can contribute to cost reductions and reduced environmental risks (Restle et al., 1999). Although the absence of pasture fertilization in Brazil is frequently a problem, high levels of $\mathrm{N}$ fertilization (exceeding plant uptake) may result in leaching, causing environmental contamination (Di \& Cameron, 2002) and lower profits.

Soil N, usually present in its solid phase in organic and inorganic form, may or not be readily available to plants (Urquiaga \& Zapata, 2000). The main organic $\mathrm{N}$ source of the soil is organic matter originated from plant residues; despite containing the largest portion of $\mathrm{N}$, this $\mathrm{N}$ is not readily available but requires a mineralization process which is very dependent on the plant residue C:N ratio and soil N availability (Santi et al., 2003). The total soil N amount in the organic and inorganic form varies from 0.5 to $5 \mathrm{~g} \mathrm{~kg}^{-1}$. Of this amount, only $5 \% \mathrm{~N}$ is present in the inorganic form, that is, readily available for plant uptake (Sá, 1999). The soil N content, its forms and plant availability depend basically on the crop species, climate and soil conditions.

Nitrogen in the $\mathrm{N}-\mathrm{NO}_{3}{ }^{-}$form is readily available to plants and also easily lost by leaching, since its electrostatic adsorption is lower than of other anions present in the solid liquid interface of the topsoil. Therefore, $\mathrm{N}^{-\mathrm{NO}_{3}}{ }^{-}$is not adsorbed to the soil, and remains in the soil solution from where it is easily lost by leaching to deeper soil layers out of reach of plant roots (Ceretta \& Fries, 1997).

The study of $\mathrm{N}$ use efficiency and recovery is therefore important for any cropping system once it affects the system sustainability. Nitrogen is indispensable for grass production and the response to $\mathrm{N}$ in plant and animal productivity is well-documented (Martins et al., 2000; Restle et al., 2002). Different grazing intensities affect the level of $\mathrm{N}$ return in urine and feces and can lead to $\mathrm{N}$ losses, e.g., by volatilization.

Nitrogen recovery in pastures varies from 50 to $65 \%$ of the total $\mathrm{N}$ applied through $\mathrm{N}$ fertilizer (Schepers \& Mosier, 1991). The $\mathrm{N}$ dynamics at a site under grazing, with $\mathrm{N}$ application (urine) between 200 and $250 \mathrm{~kg} \mathrm{ha}^{-1}$ year-1 $^{-1}$ showed that one third of total applied $\mathrm{N}$ was retained by organic matter $(25 \%)$ and by the plant root system (2-5\%). Of the remaining $\mathrm{N}$, a part is lost by ammonia volatilization after application (20\%), ammonia volatilization from the spots of excreta deposition (20-30 \%), denitrification (6-12\%) and by leaching or other types of losses, such as excretion outside the pasture $(20-50 \%)$. Another fraction goes into animal production, be it meat (7$9 \%$ ) or milk (14-18 \%) (Kimura \& Kurashima, 1991; Whitehead, 2000).

The purpose of this experiment was to evaluate $\mathrm{N}$ use efficiency and recovery rate of Alexandergrass pasture (Brachiaria - Syn. urochloa plantaginea) and determine $\mathrm{N}^{-\mathrm{NO}_{3}}{ }_{3}$ and $\mathrm{N}-\mathrm{NH}_{4}{ }^{+}$soil concentration in the soil profile under different levels of $\mathrm{N}$ fertilization and two grazing intensities. 


\section{MATERIALS AND METHODS}

This study was carried out in an experimental unit of the Instituto Agronômico do Paraná - IAPAR, from November 2007 to April 2008, in Pato Branco-PR. The experimental area is located on a plateau called Terceiro Planalto $\left(26^{\circ} 7^{\prime} \mathrm{S}, 52^{\circ} 41^{\prime} \mathrm{W}\right.$; average altitude $700 \mathrm{~m}$ asl). The regional climate is subtropical humid (Köppen classification Cfa) (Maak, 1968). The soil of the experimental site was classified as Oxisol (Embrapa, 2006). Monthly averages of temperature and rain are listed in figure 1 (Iapar, 2008).

The management system in the experimental area had been no-tillage as of 1998 , with alternating soybean and corn crops in the summer and small grains in the winter, without grazing. The experimental area corresponded to 1.39 ha, with 12 subdivisions, which constituted the experimental units and another area (0.2 ha) nearby for the grazing animals.

Prior to the experiment, the area was mowed to reduce the vegetation cover on the soil and provide best germination of Brachiaria plantaginea, which is photoblastic positive and thus needs light to germinate.

Soil chemical fertilization was performed according to recommendations of the soil fertilization manual, CQFSRS/SC (2004) and according to the values found in the soil analyses $(0-15 \mathrm{~cm}$ layer $): \mathrm{pH}-\mathrm{CaCl}_{2}=6.3$; $\mathrm{P}=10 \mathrm{mg} \mathrm{dm}^{-3} ; \mathrm{K}=293 \mathrm{mg} \mathrm{dm}{ }^{-3} ; 5.7 \mathrm{~g} \mathrm{~kg}^{-1}$ of OM; $\mathrm{Ca}=8.7 \mathrm{cmol}_{\mathrm{c}} \mathrm{dm}^{-3} ;$ Base saturation $=78 \%$ and CEC $=17.49 \mathrm{cmol}_{\mathrm{c}} \mathrm{dm}^{-3}$. As recommended for summer grasses, $60 \mathrm{~kg} \mathrm{ha}^{-1} \mathrm{P}_{2} \mathrm{O}_{5}$ were applied.

The experiment was arranged in a randomized block design in a $3 \times 2$ factorial scheme consisting of three $\mathrm{N}$ rates $\left(0,200\right.$ and $\left.400 \mathrm{~kg} \mathrm{ha}^{-1} \mathrm{~N}\right)$ and two grazing intensities $\left(2,000\right.$ and $3,600 \mathrm{~kg} \mathrm{ha}^{-1}$ of DM, corresponding, respectively, to the low and high mass treatment with a continuous grazing method with varying stocking rates). To assess the $\mathrm{N}^{-} \mathrm{NO}_{3}{ }^{-}$and $\mathrm{N}-\mathrm{NH}_{4}{ }^{+}$levels the layers of $0-5,5-10,10-20,20-30$ and $30-40 \mathrm{~cm}$ were considered as subplots.

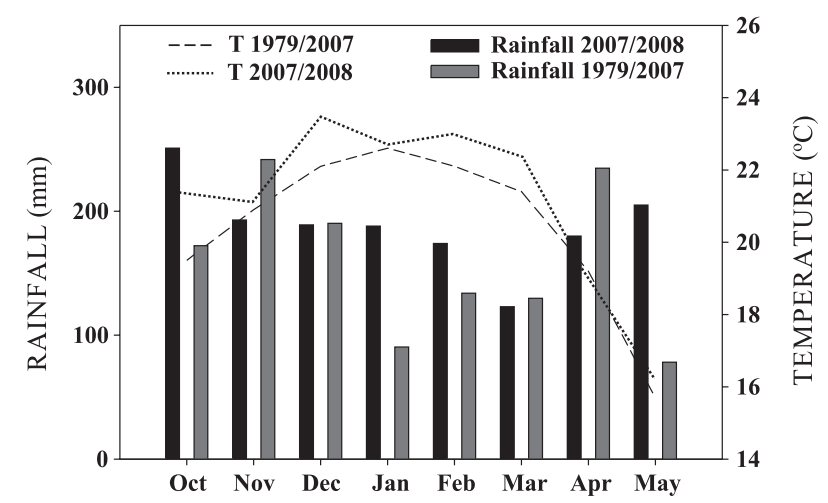

Figure 1. Historical and observed rainfall in the experimental period (Instituto Agronômico do Paraná, IAPAR, Pato Branco, PR, 2007/2008).
$\mathrm{N}$ fertilizations were split into four applications of 50 and $100 \mathrm{~kg} \mathrm{ha}^{-1} \mathrm{~N}$, corresponding to the tested levels (200 and $400 \mathrm{~kg} \mathrm{ha}^{-1} \mathrm{~N}$ ), and applied manually on the following dates: December $07^{\text {th }}$, January $11^{\text {th }}$, January $28^{\text {th }}$ and February $24^{\text {th }}$ (2007/2008), always observing the weather conditions and moisture level to make the best use of $\mathrm{N}$ by the system. The $\mathrm{N}$ source used was urea at a concentration of $45 \% \mathrm{~N}$.

Grazing intensities were adjusted by the put and take method described by Mott \& Lucas (1952). The grazing animal were goats, half-blood Boer, average age 5 months, body weight (BW) $21 \mathrm{~kg}$. Three animals were kept on each paddock and a variable number of extra animals were used to adjust the forage mass according to the treatments.

Forage accumulation $\left(\mathrm{kg} \mathrm{ha}^{-1}\right.$ day $^{-1}$ of $\left.\mathrm{DM}\right)$ was evaluated on average every 21 days, by using two grazing exclusion cages for each experimental unit, by the technique described by Moraes et al. (1990). Forage production of each period was obtained by the multiplication of the dry matter accumulation rate by the number of days of the period. Total production was obtained by the initial forage mass plus the forage production of each period and was expressed in $\mathrm{kg}$ of dry mass per hectare ( $\left.\mathrm{kg} \mathrm{ha}^{-1} \mathrm{DM}\right)$. Sub-samples were taken from the forage mass sample, dried in a forcedair oven at $60^{\circ} \mathrm{C}$ and subsequently milled in a Wiley mill with a $1 \mathrm{~mm}$ sieve and the $\mathrm{N}$ concentration determined by the Kjeldahl method described by Tedesco et al. (1995).

From the pasture DM production and its $\mathrm{N}$ content the $\mathrm{N}$ use efficiency and recovery rates were evaluated. Efficiency of $\mathrm{N}$ fertilization on forage yield (kg DM per $\mathrm{kg} \mathrm{N}$ applied) was calculated assuming that the contribution of soil $\mathrm{N}$ was similar among treatments with or without $\mathrm{N}$, subtracting from the forage yield of the treatments treated with $\mathrm{N}$ the control (without $\mathrm{N})$. The result of the subtraction was divided by the amount of $\mathrm{N}$ applied in topdressing.

Forage $\mathrm{N}$ content multiplied by forage yield enabled the determination of $\mathrm{N}$ absorbed by the pasture. Each period was evaluated this way and the addition of the periods resulted in the total $\mathrm{N}$ absorbed.

Nitrogen recovery was calculated according to the following equation:

$$
\mathrm{NR}=100(\mathrm{TN}-\mathrm{TNW}) / \mathrm{NR}
$$

where NR (\%) corresponds to $\mathrm{N}$ recovery; $\mathrm{TN}=$ total amount of $\mathrm{N}$ absorbed, with $\mathrm{N}$ application $\left(\mathrm{kg} \mathrm{ha}^{-1}\right)$; $\mathrm{TNW}=$ total amount of $\mathrm{N}$ absorbed, without $\mathrm{N}$ application $\left(\mathrm{kg} \mathrm{ha}^{-1}\right)$, and $\mathrm{NR}=\mathrm{N}$ rate applied $\left(\mathrm{kg} \mathrm{ha}^{-1}\right)$.

To estimate the dynamics of mineral $\mathrm{N}$ in the soil profile, concentrations of $\mathrm{N}-\mathrm{NO}_{3}{ }^{-}$and $\mathrm{N}-\mathrm{NH}_{4}{ }^{+}$were measured in the layers 0 to $5,5-10,10-20,20-30$ and $30-40 \mathrm{~cm}$. From the first three layers, soil was collected using a cutting blade, while from 20-30 and $30-40 \mathrm{~cm}$ a Dutch auger was used. Five sub-samples 
were collected per paddock, which together composed one sample. Samples were collected 10 days after each $\mathrm{N}$ application, on December $17^{\text {th }}$, January $21^{\text {st }}$, February $08^{\text {th }}$ and March $03^{\text {rd }}$ of 2008. Samples were dried at $55{ }^{\circ} \mathrm{C}$ for $72 \mathrm{~h}$ and soil N-NO${ }_{3}{ }^{-}$and $\mathrm{N}-\mathrm{NH}_{4}{ }^{+}$ were determined by the method described by Tedesco et al. (1995). Mineral $\mathrm{N}$ is the sum of $\mathrm{N}$ as ammonium and nitrate form.

The results were subjected to analysis of variance (ANOVA). The variances were tested by the $\mathrm{F}$ test. When the results were significant at $5 \%$, the means were compared by the Tukey test at $5 \%$.

\section{RESULTS AND DISCUSSION}

Nitrogen efficiency of use in the treatment with $200 \mathrm{~kg} \mathrm{ha}^{-1} \mathrm{~N}$ (30.87 $\mathrm{kg}$ of DM per $\mathrm{kg} \mathrm{N}$ ) was three times higher than the treatment with $400 \mathrm{~kg} \mathrm{ha}^{-1} \mathrm{~N}$, which showed an efficiency of $10.4 \mathrm{~kg}$ DM per $\mathrm{kg} \mathrm{N}$ applied. According to Mello (1987), N efficiency of use depends on factors such as climate and soil conditions, $\mathrm{N}$ source, amount applied, fractionation and response capacity of the plant.

Evaluating Brachiaria plantaginea, Martins et al. (2000) reported an N efficiency of use of $20.48 \mathrm{~kg} \mathrm{DM}$ per $\mathrm{kg}$ applied $\mathrm{N}$ at an $\mathrm{N}$ rate of $200 \mathrm{~kg} \mathrm{ha}^{-1} \mathrm{~N}$. Restle et al. (2002) reported $\mathrm{N}$ efficiency of use for the same species of 9.62 and $20.48 \mathrm{~kg}$ DM per $\mathrm{kg}$ applied $\mathrm{N}$ at rates of 100 and $200 \mathrm{~kg} \mathrm{ha}^{-1} \mathrm{~N}$, respectively. Lupatini et al. (1995) reported $\mathrm{N}$ efficiency of use of 39.3 and $31.0 \mathrm{~kg}$ DM per $\mathrm{kg}$ applied $\mathrm{N}$, respectively, at $\mathrm{N}$ rates of 150 and $300 \mathrm{~kg} \mathrm{ha}^{-1}$.

Therefore, although there were no significant differences in forage production between $\mathrm{N}$ rates of 200 and $400 \mathrm{~kg} \mathrm{ha}^{-1}$, forage production at $200 \mathrm{~kg} \mathrm{ha}^{-1}$ $\mathrm{N}$ was $10 \%$ higher than the treatment with $400 \mathrm{~kg} \mathrm{ha}^{-1}$ and N efficiency of use was $66 \%$ higher, possibly explained by plant physiological limitations or imbalance in nutrient availability (Mello, 1987).

Total $\mathrm{N}$ recovered and $\mathrm{N}$ recovery rate (Table 1 ) in the treatment with $400 \mathrm{~kg} \mathrm{ha}^{-1} \mathrm{~N}$ were 26 and $63 \%$ lower in relation to the treatment with $200 \mathrm{~kg} \mathrm{ha}^{-1}$ $\mathrm{N}$, indicating that the plant has a limited capacity of $\mathrm{N}$ use in a given period of time (Lupatini et al. 1995; Follet \& Wilkinson, 1985), which may increase N losses (Mello, 1987).

The $\mathrm{N}$ recovery rate may exceed $100 \%$ (Dougherty \& Rhykerd, 1985), as observed in this experiment. In the treatment with $200 \mathrm{~kg} \mathrm{ha}^{-1} \mathrm{~N}, \mathrm{~N}$ recovery rate was $110 \%$. In other words, N plant uptake exceeded the applied $\mathrm{N}$. This fact may be explained by the positive effect of $\mathrm{N}$ on organic matter mineralization or by the $\mathrm{N}$ present on the soil. Another explanation suggested an increase of nutrient cycling due to the grazing effect (Vicente-Chandler, 1973; Follet \& Wilkinson, 1985). For pearl millet (Pennisetum
Table 1. Forage yield, $\mathrm{N}$ recovery and total $\mathrm{N}$ recovered by Brachiaria plantaginea under $\mathrm{N}$ rates

\begin{tabular}{rccc}
\hline $\begin{array}{c}\text { N } \\
\text { rate }\end{array}$ & $\begin{array}{c}\text { Total DM } \\
\text { production }\end{array}$ & $\begin{array}{c}\text { Total N } \\
\text { recovered }\end{array}$ & N Recovery \\
\hline & $\mathrm{kg} \mathrm{ha}^{-1}$ & & $\%$ \\
\hline 0 & $13659 \mathrm{a}$ & $249.81 \mathrm{a}$ & -- \\
400 & $19834 \mathrm{~b}$ & $469.89 \mathrm{~b}$ & $110.04 \mathrm{a}$ \\
& $17820 \mathrm{~b}$ & $413.06 \mathrm{~b}$ & $40.81 \mathrm{~b}$ \\
\hline
\end{tabular}

Means in the same column followed by different letters differ $(p<0.05)$ by the Tukey test.

americanum), Lupatini (1996) reported an $\mathrm{N}$ recovery rate of $163,102,95,77 \%$ to rates of $150,300,450$ and $600 \mathrm{~kg} \mathrm{ha}^{-1} \mathrm{~N}$, respectively.

There were no significant differences between the treatments in relation to the soil $\mathrm{N}-\mathrm{NO}_{3}{ }^{-}$levels 10 days after the first $\mathrm{N}$ application, corresponding to $1 / 4$ of the total applied (Figure 2a). This indicates that the plant used the $\mathrm{N}$ applied and responded in yield once forage production in the first period was 2,$249 ; 2,767$ and $3,430 \mathrm{~kg} \mathrm{ha}^{-1}$ for the treatment without $\mathrm{N}$, with 200 and $400 \mathrm{~kg} \mathrm{ha}^{-1} \mathrm{~N}$, respectively.

This soil $\mathrm{N}$ dynamics changed during the experiment. In the evaluation 10 days after the second $\mathrm{N}$ application, $\mathrm{N}-\mathrm{NO}_{3}{ }^{-}$soil contents were higher in the surface layer (Figure 2b,c,d), especially in the treatments with 200 and $400 \mathrm{~kg} \mathrm{ha}^{-1} \mathrm{~N}$. Soil traits such as high content of organic matter (5.7\%) and clayey texture (Embrapa, 2006), allows greater attraction of ions (Ernani \& Barber, 1993) and contribute to larger amounts of $\mathrm{N}^{-\mathrm{NO}_{3}}{ }^{-}$in the soil surface layers. Moreover, the no-tillage system may have contributed to this fact, once according to Assmann (2001), in no-tillage systems nutrients accumulation in the soil surface layers is expected, decreasing the probability of $\mathrm{N}$ leaching.

There were no differences in $\mathrm{N}_{-} \mathrm{NO}_{3}{ }^{-}$soil content at depths below $10 \mathrm{~cm}$ between the treatment with $200 \mathrm{~kg} \mathrm{ha}^{-1} \mathrm{~N}$ and without N (Figure 2) indicating no $\mathrm{N}-\mathrm{NO}_{3}^{-}$leaching problems due to $\mathrm{N}$ uptake by the forage plant for production. Furthermore, most of the roots $(80 \%)$ are in the surface soil layer of 0 to $40 \mathrm{~cm}$ (Primavesi et al., 2001), enabling plant $\mathrm{N}_{-} \mathrm{NO}_{3}{ }^{-}$ absorption.

Evaluating $\mathrm{N}-\mathrm{NO}_{3}{ }^{-}$leaching down to a depth of $160 \mathrm{~cm}$, Primavesi et al. (2006) also observed greater variations in the first $40 \mathrm{~cm}$ of the soil profile. The authors reported that in soil of medium texture under tropical grass such as coastcross (Cynodon dactylon), there is no risk of groundwater contamination even at high rates of $\mathrm{N}$ (500 and $\left.1,000 \mathrm{~kg} \mathrm{ha}^{-1} \mathrm{yr}^{-1}\right)$, however, it is important not to exceed the $\mathrm{N}$ uptake capacity of the grass and consider the $\mathrm{N}$ supply 

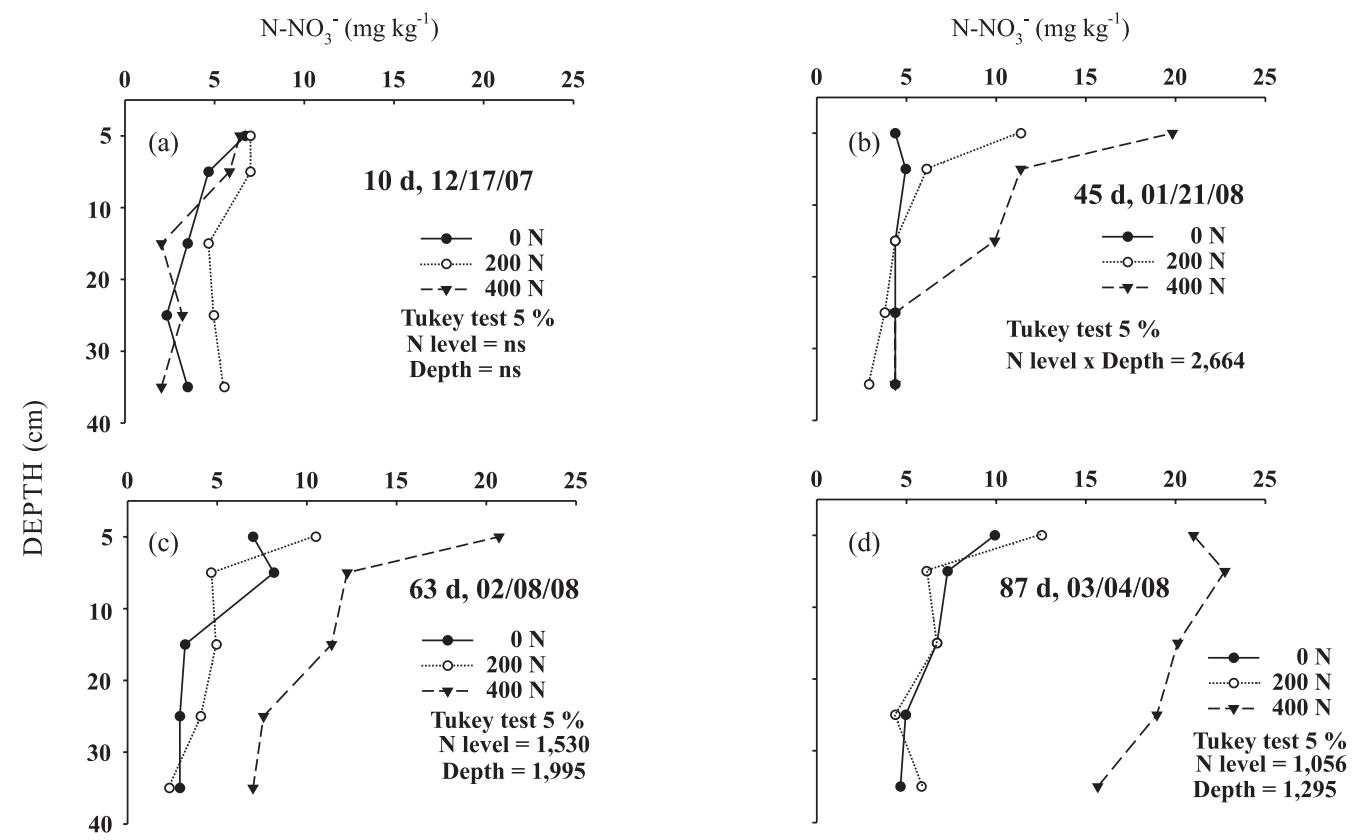

Figure 2. Soil $\mathrm{N}_{-} \mathrm{NO}_{3}{ }^{-}$levels in relation to different $\mathrm{N}$ rates $\left(0,200\right.$ and $\left.400 \mathrm{~kg} \mathrm{ha}^{-1} \mathrm{~N}\right)$ in the soil profile (depth $40 \mathrm{~cm}$ ) under Alexandergrass (Brachiaria plantaginea).

capacity of the soil. Rainfall intensity was not sufficient to cause $\mathrm{N}-\mathrm{NO}_{3}{ }^{-}$leaching, because, according to Drouineau (1969), this form of $\mathrm{N}$ loss in the soil profile is influenced by the downward flow of water in the soil.

There was $\mathrm{N}^{-} \mathrm{NO}_{3}{ }^{-}$accumulation in the first $40 \mathrm{~cm}$ of the soil profile in the treatment with $400 \mathrm{~kg} \mathrm{ha}^{-1}$. This was related to the lower forage yield in this treatment compared to the treatment with $200 \mathrm{~kg} \mathrm{ha}^{-1}$ N (Table 1).

Phosphorous $(\mathrm{P})$ nutritional limitations, indicated by the lower $\left(1.2 \mathrm{~g} \mathrm{~kg}^{-1} \mathrm{DM}\right)$ content of $\mathrm{P}$ in plant tissue (Guss et al., 1990) may be responsible for the lack of yield response in the treatment with $400 \mathrm{~kg} \mathrm{ha}^{-1} \mathrm{~N}$. Therefore, application of high $\mathrm{N}$ amounts should be accompanied by the use of $\mathrm{P}$ and $\mathrm{K}$ fertilization for a plant response in yield, aside from preventing soil $\mathrm{N}$ leaching.

Soil $\mathrm{N}-\mathrm{NO}_{3}{ }^{-}$accumulation, especially in Oxisols that have a thick $\mathrm{B}$ horizon with higher Anion Exchange Capacity (AEC) and therefore a lower of groundwater contamination risk, can provide benefits subsequent crops and soil quality being recommended in areas with integrated crop-livestock system.

In terms of animal influence on $\mathrm{N}$ dynamics, greater $\mathrm{N}-\mathrm{NO}_{3}{ }^{-}$concentration was observed in the soil surface layer $(0-5 \mathrm{~cm})$ at both grazing intensities after the second evaluation. However, at higher forage mass $\left(3,600 \mathrm{~kg} \mathrm{ha}^{-1} \mathrm{DM}\right)$, i.e., lower stocking rate, soil $\mathrm{N}-\mathrm{NO}_{3}{ }^{-}$levels were lower than the treatment with low forage mass $\left(2,000 \mathrm{~kg} \mathrm{ha}^{-1} \mathrm{DM}\right)$ i.e., higher stocking rate.
In the high forage mass treatments, the $\mathrm{N}$ immobilization rate in the organic matter mineralization process may have been higher, due the higher herbage mass and greater $\mathrm{N}$ demand for the process. On the other hand, in the treatment with low mass (higher stocking rate), $\mathrm{N}-\mathrm{NO}_{3}{ }^{-}$is subject to greater losses, since it is present in larger amounts in the soil solution and is not being absorbed by the plant. Furthermore, when the forage mass is lower, stocking rate is higher, consequently increasing the dung deposition (animal urine and feces), returning greater amounts of $\mathrm{N}$ to the soil than at lower stocking rate or larger forage mass.

Soil N-NO ${ }_{3}^{-}$levels, even at higher $\mathrm{N}$ rates, showed no toxic effects to plants, since plants tolerate excess of $\mathrm{N}-\mathrm{NO}_{3}^{-}$by accumulating high levels in its tissues, unlike $\mathrm{N}-\mathrm{NH}_{4}{ }^{+}$which can cause problems for plant growth at high concentrations (Tisdale et al., 1993).

With regard to the soil N- $\mathrm{NH}_{4}{ }^{+}$levels, no significant influence of the interactions of the factors on the $B$. plantaginea pasture were observed and there was no influence of grazing intensity and sampling depth on this dependent variable with an average soil content of $6.5 \mathrm{mg} \mathrm{dm}{ }^{-3} \mathrm{~N}-\mathrm{NH}_{4}{ }^{+}$. However, there was a significant influence $(\mathrm{p}<0.0366)$ of $\mathrm{N}$ rates. The soil $\mathrm{N}-\mathrm{NH}_{4}{ }^{+}$content was 5.8, 6.4 and $7.3 \mathrm{mg} \mathrm{dm}^{-3}$ at 0 , 200 and $400 \mathrm{~kg} \mathrm{ha}^{-1} \mathrm{~N}$ respectively; the treatment with $400 \mathrm{~kg} \mathrm{ha}{ }^{-1} \mathrm{~N}$ differed significantly $(\mathrm{p}>0.05)$ from the treatment without $\mathrm{N}$.

Adequate chemical, physical and biological soil traits associated with good levels of organic matter in the experimental area provided rapid nitrification, 

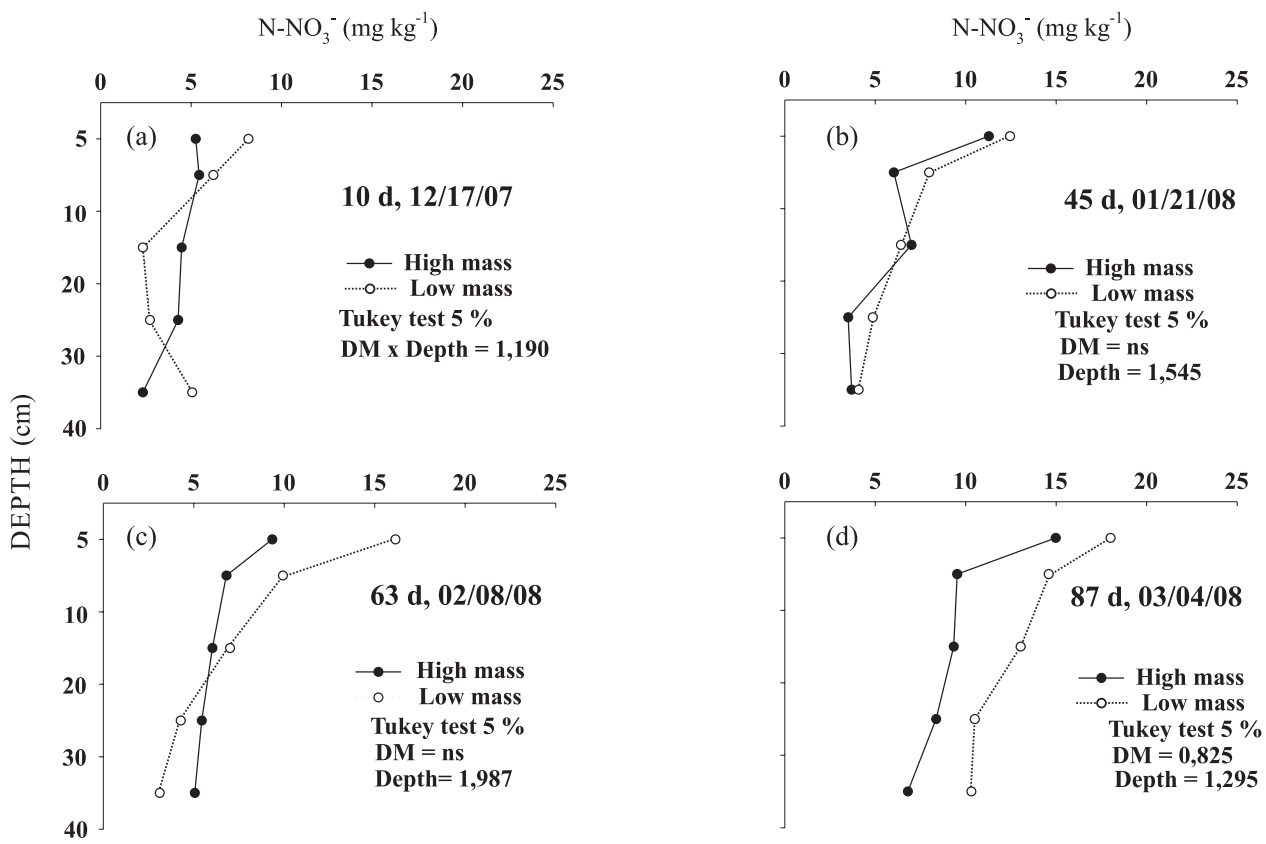

Figure 3. Soil N-NO ${ }_{3}^{-}$levels in relation to different forage mass (HM=3,600 $\mathrm{kg} \mathrm{ha}^{-1}$ of DM and LM=2,000 kg ha-1 of DM) in the soil profile (depth $40 \mathrm{~cm}$ ) under Alexandergrass (Brachiaria plantaginea).

since $\mathrm{N}$ as ammonium does not remain in large quantities (Malavolta, 1981; Raij, 1991), indicating low rates of soil $\mathrm{N}-\mathrm{NH}_{4}{ }^{+}$and little variation between levels and no variation between soil layers and assessed periods. Furthermore, in aerated soil, $\mathrm{N}_{-} \mathrm{NO}_{3}{ }^{-}$is the main form of inorganic $\mathrm{N}$ available for plant growth. On the other hand, ammonia is the prevailing form in soils with high acidity and moisture, which was not the case of the soil in this study (Raij, 1991).

Most $\mathrm{N}$ applied may have been used in the mineralization of organic matter, especially in the case of grasses, which according to Alexander (1980) have a high capacity of N immobilization. Assmann (2001) considered the increased availability of $\mathrm{N}$ mineral a positive factor since the nutrient is in a readily available form for plants, but also reports that this availability may expose the nutrient to more intense leaching processes, which can be aggravated when deposited on the soil as animal urine.

\section{CONCLUSIONS}

1. Best $\mathrm{N}$ use efficiency and recovery rate were obtained by the use of $200 \mathrm{~kg} \mathrm{ha}^{-1} \mathrm{~N}$, resulting in a higher forage yield and lower soil $\mathrm{N}-\mathrm{NO}_{3}$ accumulation.

2. There was soil $\mathrm{N}^{-} \mathrm{NO}_{3}{ }^{-}$accumulation at the depth of $40 \mathrm{~cm}$ at $400 \mathrm{~kg} \mathrm{ha}^{-1} \mathrm{~N}$, although the total $\mathrm{N}$ applied was split in four applications.
3. N application of up to $200 \mathrm{~kg} \mathrm{ha}^{-1}$ on Brachiaria plantaginea poses no risk of environmental contamination in Oxisol.

4. There is a trend of greater $\mathrm{N}^{-\mathrm{NO}_{3}}{ }^{-}$accumulation in soils under higher grazing intensities, which may be the major input of readily available $\mathrm{N}$ for the following crop on the one hand, or allow $\mathrm{N}$ losses and environmental contamination on the other.

\section{ACKNOWLEDGEMENTS}

The authors are indebted to the Instituto Agronômico do Paraná - IAPAR and to Universidade Tecnológica Federal do Paraná - UTFPR.

\section{LITERATURE CITED}

ALEXANDER, M. Descomposición de la materia orgánica. In: ALEXANDER, M. Introducción a la microbiologia del suelo. Mexico, AGT, 1980. p.142-162.

ASSMANN, T.S. Rendimento de milho em área de integração lavoura-pecuária sob sistema de plantio direto, em presença e ausência de trevo branco, pastejo e N. Curitiba, Universidade Federal do Paraná, 2001. 59p. (Tese de Doutorado)

CERETTA, C.A \& FRIES, M.R. Adubação nitrogenada no sistema de plantio direto. In: NUERNBERG, N.J. Plantio direto: Conceitos, fundamentos e práticas culturais. Lages Sociedade Brasileira de Ciência do Solo, Núcleo Regional Sul, 1997. p.111-120. 
COMISSÃO DE QUÍMICA E FERTILIDADE DO SOLO . CQFSRS/SCRS/SC. Manual de adubação e calagem para os Estados do Rio Grande do Sul e de Santa Catarina. 10.ed. Porto Alegre, SBCS/NRS, 2004. 400p.

DI, H.J. \& CAMERON, K.C. Nitrate leaching and pasture production from different nitrogen sources on a shallow stony soil under flood-irrigated dairy pasture. Austr. J. Soil Res., 40:317-334, 2002

DOUGHERTY, C.T. \& RHYKERD, C.L. The role of nitrogen in forage-animal production. In: HEATH, M.E.; BARNES, R.F. \& METCALFE, D.S., eds. FORAGES: THE SCIENCE OF GRASSLAND AGRICULTURE, 1985, Ames. Anais...Ames, Iowa State University Press, 1985. p.318. 325 .

DROUINEAU, G. Influence of irrigation on the distribution of fertilizer elements in the soil profile. In: COLLOQUIUM OF THE INTERNATIONAL POTASH INSTITUTE, 7. Bern, 1969. Anais... Bern, International Potash Institute, 1969. p.96-105.

EMPRESA BRASILEIRA DE PESQUISA AGROPECUÁRIA EMBRAPA. Sistema brasileiro de classificação de solos. 2.ed. Rio de Janeiro, Embrapa Solos, 2006. 306p.

ERNANI, P.R. \& BARBER S.A. Composição da solução do solo e lixiviação de cátions afetadas pela aplicação de cloreto e sulfato de cálcio em um solo ácido. R. Bras. Ci. Solo, 10:4146, 1993.

FOLLETT, R.F. \& WILKINSON, S.R. Soil fertility and fertilization of forages. In: FORAGES: THE SCIENCE OF GRASSLAND AGRICULTURE, Ames, 1985. Anais...Ames, Iowa State University Press, 1985. p.304317.

GUSS, A.; GOMIDE, J.A. \& NOVAIS, R.F. Exigência de fósforo para o estabelecimento de quatro espécies de Brachiaria em solos com características físico-químicas distintas. R. Bras. Zootec., 19:278-289, 1990.

INSTITUTO AGRONÔMICO DO PARANÁ - IAPAR. [2007]. Disponível em: <http://www.iapar.br/modules/ canteudo.htm> Acesso em: 08 de nov. 2008.

KIMURA, T. \& KURASHIMA, K. Quantitative estimates of the budgets of nitrogen applied as fertilizer, urine and feces in a soil. Grass. System., 25:101-107, 1991.

LUPATINI, G.C. Produção animal em milheto (Pennisetum americanum (L.) Leeke) submetido a níveis de adubação nitrogenada. Santa Maria, Universidade Federal de Santa Maria, 1996. 126p. (Tese de Mestrado)

LUPATINI, G.C.; MOOJEN, E.L. \& RESTLE, J. Avaliação de milheto (Pennisetum americanum (L.) Leeke) sob pastejo com níveis de N. Pesq. Agropec. Bras, 31:715-720, 1995.

MAAK, R. Geografia física do estado do Paraná. Curitiba, Banco de Desenvolvimento do Paraná, 1968. 350p.

MALAVOLTA, E. Manual de química agrícola - adubos e adubações. 3.ed. São Paulo, Agronômica Ceres, 1981, 596p.

MARTINS, J.D.; RESTLE, J. \& BARRETO, I.L. Produção animal em capim papuã (Brachiaria plantaginea (Link) Hitchc) submetido a níveis de N. Ci. Rural, 30:887-892, 2000 .
MELLO, F.A.F. Uréia fertilizante. Campinas, Fundação Cargil, 1987.192p.

MORAES, A.; MOOJEN, E.L. \& MARASCHIN, G.E. Comparação de métodos de estimativa de taxas de crescimento em uma pastagem submetida a diferentes pressões de pastejo. In: REUNIÃO ANUAL DA SOCIEDADE BRASILEIRA DE ZOOTECNIA, 27., Campinas, 1990. Anais... Campinas, SBZ, 1990. p.332.

MOTT, G.E. \& LUCAS, H.L. The design, conduct and interpretation of grazing trials on cultivated and improved pastures. In: INERNATIONAL GRASSLAND CONGRESS, 6., Pennsylvania, 1952. Proceedings... Pennsylvania, State College Press,1990. p.1380.

PRIMAVESI, O.; CORREAA, L.A.; PRIMAVESI, A.C.; CANTARELlA, H.; ARMELIN, M.J.A.; SILVA, A.G. \& FREITAS, A.R. Adubação com uréia em pastagem de Cynodon dactylon cv. Coastcross: Eficiência e perdas. São Carlos, Embrapa Pecuária Sudeste, 2001. 42p. (Circular Técnica, 30)

PRIMAVESI, O.; PRIMAVESI, A.C.; CORRÊA, L.A.; SILVA, A.G. \& CANTARELLA, H. Lixiviação de nitrato em pastagem de coastcross adubada com nitrogenio. R. Bras. Zootec. 35:683-690, 2006.

RAIJ, B.van. Fertilidade do solo e adubação. São Paulo, Agronômica Ceres, 1991. 343p.

RESTle, J.; ROSO, C. \& SOARES, A.B. Produção animal e retorno econômico em misturas de gramíneas anuais de estação fria. R. Bras. Zootec., 28:235-243, 1999.

RESTLE, J.; ROSO, C.; AITA, V.; NORNBERG. J.L.; BRANDANI, I.V.; CERDÓTES, L. \& CARRILHO, C.O. Produção animal em pastagem com gramíneas de estação quente. R. Bras. Zootec., 31:1491-1500, 2002.

SÁ, J. C. M. Manejo da fertilidade do solo no sistema plantio direto. In: SIQUEIRA, J. O.;. MOREIRA, F. M. S.; LOPES, A. S.; ... Inter-relação fertilidade, biologia do solo e nutrição de plantas. Viçosa, MG: SBSC; Lavras: UFLA, 1999. p. 267-319.

SANTI, A.; AMADO, T.J. C. \& ACOSTA, J.A.A. Adubação nitrogenada na aveia preta - Influência na produção de matéria seca e ciclagem de nutrientes sob sistema plantio direto. R. Bras. Ci. Solo, 27:1075-1083, 2003.

SCHEPERS, J.S. \& MOSIER, A.R. Accounting for nitrogen in nonequilibrium soil-crop systems. In: FOLLETT, R.F.; KEENEY, D.R. \& CRUSE, R.M., eds. Managing nitrogen for groundwater quality and farm profitability. Madison, Soil Science Society of America, 1991. p.125-138.

TEDESCO, M.J.; GIANELLO, C.; BISSANI, C.A.; BOHNEN, H. \& VOLKWEISS, S.J. Análise de solo, plantas e outros materiais, Porto Alegre, Departamento de Solos da UFRGS, 174p. 1995.

TISDALE, S.L.; NELSON, W.L. \& BEATON, J.D. Soil fertility and fertilizers. New York, Macmillan Publishing Company, 1993. 634p.

URQUIAGA, S. \& ZAPATA, F. Manejo eficiente de la fertilización nitrogenada de cultivos anuales em América Latina y el Caribe. Porto Alegre, Gênese, 2000. p.25-29. 
VICENTE-CHANDLER, J. Intensive grassland management in Puerto Rico. R. Bras. Zootec., 2:173-215, 1973.
WHITEHEAD, D.C. Nutrient elements in grasslands: Soilplant-animal relationships. Wallingford, CAB, 2000. 369p. 